\title{
Ore Loses and Dilution of the Ore Vein No. 4 in the Zletovo Mine, Republic of Macedonia
}

\author{
NIKOLA L. BOGATINOVSKI, Geohidroinženering DOOEL, Skopje, R. Macedonia \\ TODOR S. SERAFIMOVSKI, University Goce Delcev, \\ Professional paper \\ Faculty of Natural and Technical Sciences, Štip, R. Macedonia \\ $U D C:$ 622.344(497.7) \\ GORAN K. TASEV, University Goce Delcev, \\ Faculty of Natural and Technical Sciences, Štip, R. Macedonia
}

\begin{abstract}
Zletovo mines have a tradition of exploration and exploitation of vein lead-zinc ores for almost a century. Ore losses and dilutions have always been imperative in production since traditional old methods of mining and low-productivity mineralization are used. In conditions of classical and sub-level method excavations used, the calculated ore losses in ore vein No. 4 are 13.5\%, while at the level of all excavations in the Zletovo mines dilution averages at 10\%. Ore dilution is also an important technical parameter and several possible variants were calculated. When analyzing the dilution that occurs during the preparation of the sub-level corridor with parameters such: different drop angle $\left(45-60^{\circ}\right)$, constant thickness of $1.47 \mathrm{~m}$ as the average vein thickness in the calculated ore reserves, width of the sub-level corridor of $1.57 \mathrm{~m}$ or to the width of the ore vein No. 4 were added $10 \mathrm{~cm}$ (left and right to $5 \mathrm{~cm}$ ) as much as is taken in the calculation of the planned dilution and height of $2.5 \mathrm{~m}$ as suggested for this mining method, it can be noticed that the planned dilution during this method of mining ranges from $26.3 \%$ to $42.3 \%$. In conditions of use of this underground method of excavation, parameters are selected that allow for the indicated lowering of the dilution. Namely, the thickness of the ore wire would be 1.47 $\mathrm{m}$, the mining width would be $1.57 \mathrm{~m}$, only $10 \mathrm{~cm}$ (left and right up to $5 \mathrm{~cm}$ ) to the thickness of the ore vein will be added, the height difference between the consecutive levels would be $7.5 \mathrm{~m}$, dip angle of 45 to $60^{\circ}$, and with the excavation the whole ore vein would be covered in height. On the basis of these parameters, models were prepared in which the ore vein would have a different dip angle, from which the values for the planned ore dilution ranged from 6.7 to $7.8 \%$, which is significantly lower than the average dilution in the Zletovo Mine.
\end{abstract}

Key words: lead-zinc ore, Zletovo mine, ore loses, ore dilution, $R$. Macedonia

\section{INTRODUCTION}

In terms of the balance ore reserves in mineral deposits, extracted ore always shows some differences in terms of quantity and quality. The difference in the amount of useful components contained in the ore in terms of quantity is obtained by extraction and processing means the degree of utilization of the ore expressed by coefficient of ore losses and coefficient of dilution.

The terms "dilution", "depletion" and "losses" ore

Author's address: Nikola Bogatinovski, Geohidroinženering DOOEL, Skopje, Bulevar Jane Sandanski 114, R. Macedonia

e-mail: nbogatinovski@gmail.com

Paper received: 04.07.2017.

Paper accepted: 19.07.2017. often variously defined, interpreted and determined although in fact they are the same or quite the same terms. Classification of these terms suggested by [1], is the most suited to the conditions in the "Zletovo" mine and as such it is used for a longer period:

Ore losses represent a loss, exhaustion of part of the ore reserves for various reasons. The loss of ore is divided into two categories [2]: Ore losses in narrow sense represent the unused portion of the ore reserves, which remained unexploited within the deposit (safety/protective pillars, parts of ore veins that were not enclosed within the exploitation project etc.). Losses in the broader sense are part of the ore that is lost during exploitation.

Ore dilution represents the content reduction of useful components in the ore excavated mass relative to the content of useful components in the ore body before excavation. 


\section{ORE LOSSES}

The division of ore losses during ore excavation to losses of the narrow and losses of the broader sense is due to their nature and mode of occurrence [2]. In regards to value these are two different categories, because for example ore losses of the broadest sense, arise in the process of work, for that amount of ore has been invested an effort with a certain value, while for the ore losses of the narrow sense were invested only certain financial means during the exploration.

In view of the definition there are differences, also. The amount of ore which is covered by the losses in the broader sense is irretrievably lost during exploittation, while the amount is covered by losses in the narrow sense can, under certain conditions, to be further used or excavated [3]. Losses of the narrow sense at the Zletovo mine represent that amount of ore that is left within safety pillars (Figure 1), which permanently remain un-excavated and represent loss of the mineral resource.

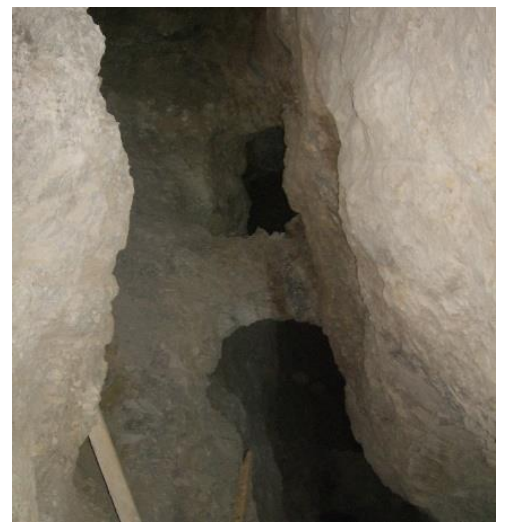

Figure 1 - Left protective mine pillars, Zletovo Mine

Also, ore losses are caused by leaving protective plates that are left under and over the mine levels (3-5 m) from which preparation and exploitation of the ore blocks are carried out, only in cases of targeted corridors for transporting the ore (Figure 2).

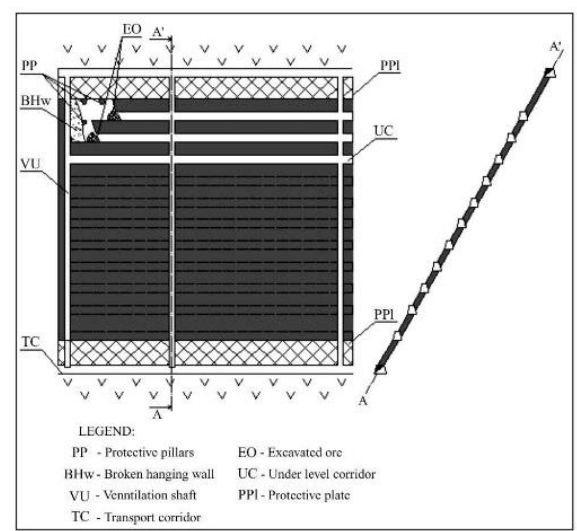

Figure 2 - Sublevel method of exploitation, with a display of protective pillars and plates, Zletovo Mine
However, a large number of these protective plates are later exploited before the definitive abandonment of that part of the deposit, except for the thinner and poorer parts of the ore veins. The ore losses that remain in the sides of the excavations are not common in the ore vein No. 4, only unexploited quantity of weakly mineralized impregnation zones are possible.

Ore losses of the wider sense are of higher importance within the Zletovo mine, and as such within the vein No. 4, these losses occur due to:

- Use of classical mining method (Figure 3), as well as due to the fall of the small fractions of the mineral grains (galena, sphalerite) in the drip, due to the inadequate granulation of the ore. Solution to this problem can be sought in artificially disabling the collapse of those minerals in the drip by placing tinned bins or a small fills from the surface of the terrain. These losses can be difficult to measure and can be overcome by taking the above measures.

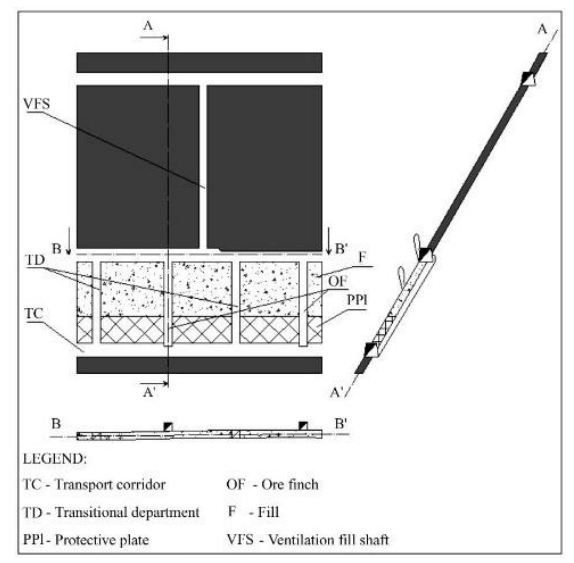

Figure 3 - Classic "Zletovo" method of exploitation

Losses caused by improperly guided exploitation have high importance because there is a high amount of ore left in the hanging wall of the ore blocks, where the length of excavation is not in accordance with the length of the mineralization, where it is estimated by insufficiently qualified persons.

Ore losses that arise due to the unjustified abandonment of already active excavations, in such cases, the justification is required in the unfavorable mining and technical conditions for the operation of such excavations (although these conditions should be provided in time). These ore losses, all together with the amount of ore reserves explored by mining operations, and remained unexploited in the abandoned parts of the deposit, represent the major ore losses from the explored ore reserves within the Zletovo Mine. Such ore reserves are named "blocked ore reserves." The reason for such situations is exclusively of a subjective character, because main target it has always been to explo it the rich ore, with more favorable conditions for 
exploitation, to cover the low productivity and some organizational weaknesses. Part of these ore reserves, before the collapse of particular mining workings and the abandonment of certain parts of the deposit, could be unequivocally exploited, but for eventual re-activation there is no economic justification. These ore losses greatly affect the depletion of the deposit and its irrational use. And if we accept that blocked ore reserves are off-balance sheet, that is, conditionally onbalance sheet, we cannot assume that the previously estimated reserves are not ore losses.

Ore losses that occur during the transport of ore to flotation are practically negligible, since the ore that falls of ore wagons, later by cleaning the corridors, is reused.

Finally, it is very important to note that the losses of useful components due to insufficient attention when loading and transporting the concentrate to processors, the insufficient accuracy of the means of weight measurement, determining the quality and moisture, significantly affect the rational use of the mineral resource.

\section{CALCULATION OF ORE LOSSES}

The calculation of losses that occur during the exploitation phase can be done in many ways. In the lead-zinc Zletovo mine, the display and calculation of ore reserves is carried out using the excavation maps, on which the ore reserves are displayed in a vertical plane. This mode of display is best suited for calculating and monitoring the exploitation of vein type deposits. On these maps, ore reserves are displayed in a vertical plane as an appropriate surface which is multiplied by the mean thickness of the ore vein that gives us the volume for that ore block, these values further by multiplying the volume weight of the ore give us the weight of the ore for that ore block. The coefficient of ore losses of the mineral resource can be calculated according to the formula [4]:

$$
\mathrm{K}=\frac{P-P_{1}}{P}
$$

where: $P$ - An area included in exploitation $\left(\mathrm{m}^{2}\right) P_{l^{-}}$An exploitetd area $\left(\mathrm{m}^{2}\right)$

Ore vein No. 4 , in the past was exploited until 2001 , during that period, an area of $280840 \mathrm{~m} 2$ was excavated, from which an ore surface of $242913 \mathrm{~m} 2$ was mined out, the area that remains untreated is 37 $927 \mathrm{~m} 2$. By applying the above formula it is obtained:

$$
\kappa=\frac{280840-242913}{280840}=0.135
$$

Calculation of the ore losses coefficient of the mineral resource is 0.135 (expressed in percent 13.5\%). The calculation take $\mathrm{s}$ into account data registered by the mine survey, but taking into account the remaining non-registered pillars, the ore losses that have occurred during transport, etc, so we may conclude that the ore losses are higher [5].

The reasons why the entire area that was covered by the exploitation was not mined should be required in reducing the lead and zinc content, the reduced thickness of the ore vein, the unfavorable physicomechanical characteristics of the environment, etc., no matter what the cause All adverse factors need to be foreseen in time, and with a series of measures they should be annulled, for example:

- With the reduction of the average content of lead and zinc, it is not necessary to abandon the excavation, but by reducing the mining width and applying appropriate mechanization it is possible to uplift that part so that the total utilization would increase.

- Also, in the case of unfavorable physical and mechanical characteristics of the geological setting, it is necessary to permanently support it, which should be excavated and used again.

- The occurrence of underground waters, which highly affects the stability of the geological setting, should be captured and drained in an appropriate way, so that the process of exploitation would proceed smoothly and the entire mineral resource would be mined up.

All of these measures, which we mentioned, in combination with others, would contribute to reducing the ore losses and thereby increasing the total utilization of the mineral resource. With extensive monitoring of the ore losses of mineral resources by the Zletovo mine geological survey, an average value of the ore losses of about $10 \%$ has been determined. Calculations made by us have resulted in higher values for the ore losses that occurred during the exploitation of the ore vein No. 4 than the average values for the deposit, so during its future exploitation, all unfavorable factors need to be predicted in time at the time of the design of the new mining research works, which would reduce the ore losses of the mineral resource to the average for the entire deposit. In the subsequent calculations of the ore reserves and the geological-economic assessment of the ore vein No. 4 , the total ore losses will be taken as $10 \%$.

\section{ORE DILUTION}

The basic factors on which the degree of ore dilution of the ore depends on the excavation of the ore veins in the Zletovo mine are grouped into geological and techno-economic factors.

A) The most important geological factors include: -The shape, size, and conditions of the ore vein 
position have considerable significance for the general size of the so-called "planned" ore dilution. This factor is especially important when mining the parts of the ore veins with very variable thickness (at short distances), which is why it is often very difficult to adjust the width of mining to them. In the thin ore veins, mining is reduced to the adopted minimum working width of $1.20 \mathrm{~m}$ (Figure 4 ), with which the ore dilution is inevitable, but it can be reduced in how the excavation of certain parts of the ore wires would be done in a selective way.

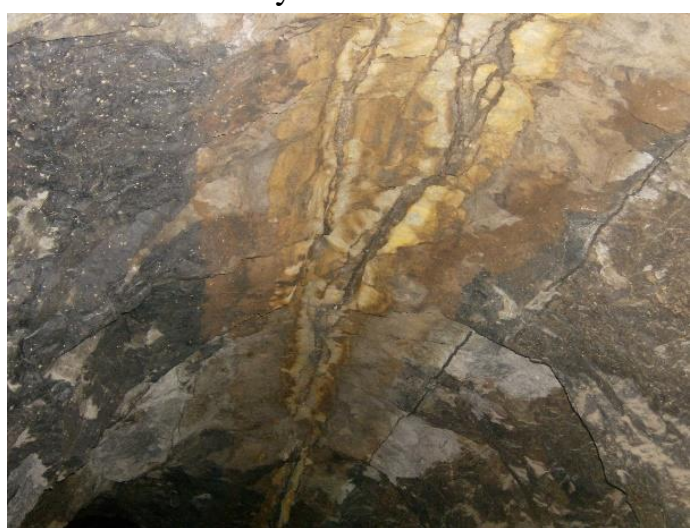

Figure 4 - View of a narrow ore vein in mining corridor

The spatial position of the ore veins affects the degree of ore dilution that in parts with milder dipping angles there is a greater possibility of breaking off the hanging wall with waste material while this possibility in steeper dipping angle veins is less pronounced.

The character of the contact of the ore wire and the surrounding rocks. The common feature of the salbands and certain ore veins is their higher or lower degree of kaolinization. The thicker ore veins have thicker salbands and vice versa.

The physical-mechanical properties of the ore and surrounding rocks have not been investigated so far, but however, it is commonly known that if the hardness of the surrounding rocks is larger than the hardness of the ore, then the ore dilution is smaller and vice versa. Particularly disadvantageous are the clay salbands that "detach", mix with the ore, stick to the galena, and thus make it difficult to dig the ore through the ore fins. From this it follows that prior to the preparation of the new excavations, the physical and mechanical properties of the ore and the surrounding rocks should be well known beforehand, in order to avoid ore losses due to the use of an inappropriate mining method.

However, the most common case is that the ore veins are more stable than the surrounding rocks, or their kaolinized salbands. Such unequal stability negatively affects the permanence of the excavation, the uncertainty in the work due to frequent deflation of large pieces with unapproved granulation, the need for subgrading, and especially this instability affects the ore dilution.

Post-mineralization tectonics. With so far carried exploration on the ore vein No. 4 at the Zletovo deposit, the impact of the intermittent tectonics of the morphological stability of the ore vein (larger transverse faults) is negligible. However, great practical significance has the syn-mineralization movements that differently manifested in certain parts of the ore vein, especially in the footwall, kaolinized salbands, and so on. These are smooth faulting mirrors in the footwall and hanging wall of the ore vein, along which, when mine, often slide large blocks of ore and surrounding rocks.

From the foregoing, it appears that geological conditions adversely affect the degree of ore dilution, and partly to the ore losses during the mining process. Therefore, attention and efforts should be paid for as much as possible to overcome them.

B) Among the technical-economic factors, which have a special influence on the degree of ore dilution of the ore during the mining, we distinguish:

- Dispatch of mine holes during mining represents one of the most important factors for regulating the inflow of slag in the ore. According to the past experience, it can be concluded that the iregular layout of the mine holes, their depth and filling with explosives have the greatest influence on the degree of ore dilution in the Zletovo mine. In the thin and medium-sized parts of the ore vein, the mine holes are usually drilled in salbands (footwall and hanging wall kaolinized zones), because these zones are the easiest for drilling due to the small hardness. Therefore, during the mine blasting fells off the kaolinized and sterile salband parts, which leads to the expansion of the excavations in those unmineralized parts. Therefore, the content of the useful components in the excavated ore mass decreases and the percentage of ore dilution increases. Input of waste in the ore is also closely related to the depth of the mine holes, their filling with explosives and their mutual layout. The condition deteriorates if the mine hole does not follow the ore vein in its direction (Fig. 5) or dip (Figure 6), or as the angle between them and the plane of the ore vein increase.

- Intensity of mining in the Zletovo mine is not at satisfactory level, and the excavated surface is much larger compared to the annual plan for ore production. The poor intensity of mining (long stoppage periods at excavations), results in natural arched excavation workings leading to instability and collapse of salbands due to seismic shocks in the excavation of other parts of excavations and 
other mining premises, constant moistening of kaolinized salbands with water which normally leads to a greater flow of slag in the ore. This suggests that the intensity of mining has a major influence on the degree of ore dilution, namely by more intensive mining, the ore dilution decreases and vice versa.

- The height of the excavation when classical method of mining is applied affects the ore dilution due to fact that larger free surface of the sides are created, and thus there is a greater possibility of their collapse. Therefore, the time distance between the excavation of the ore and the next fill of that free space should be kept to a minimum.

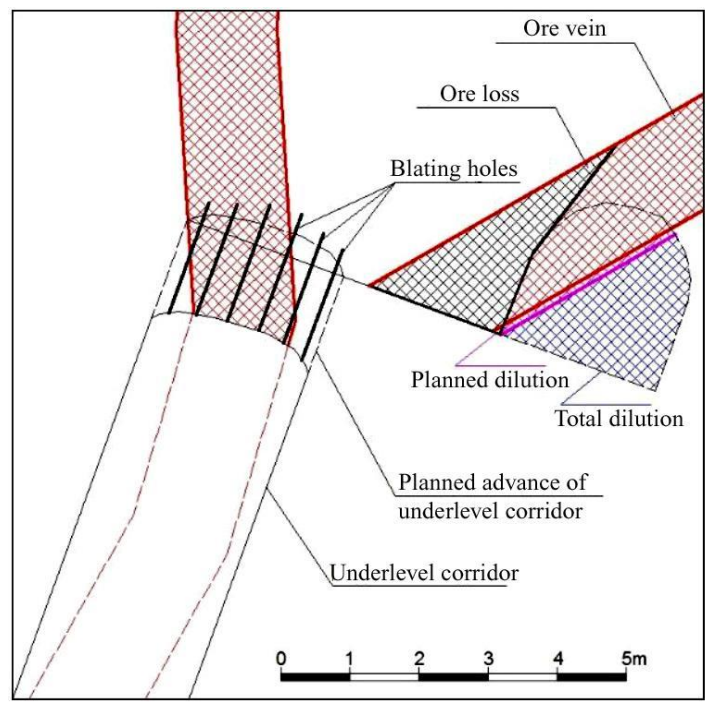

Figure 5 - Case when mine holes do not follow direction of the ore vein

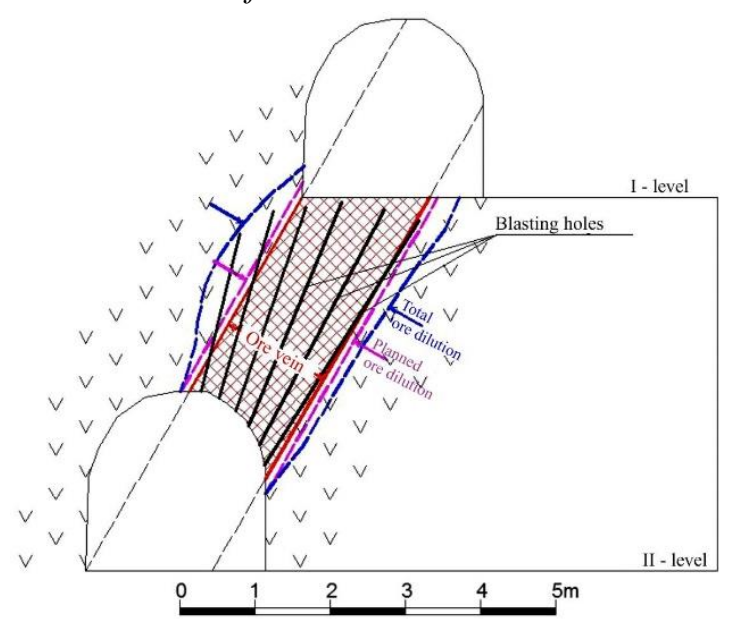

Figure 6 - Case when mine holes do not follow the dip angle of the ore vein

The following excavation methods have been used in the mine Zletovo:

A) The method of filling the empty space (classicZletovo method) has, in addition to its good sides, features that adversely affect the ore dilution. One of the most important is the unadjusted granulation of the filling material, which causes a certain amount of ore minerals (galena, sphalerite) to be lost in it. Therefore, the content of the useful components in the fill, especially in the thin parts of the ore veins, may be equal to the excavated mass. Resolving of this problem in thin ore veins should be sought in spreading tinned bins before each blasting, and in thicker ore wires to provide a drip with more favorable granulation and the top layer of the dew (about $10 \mathrm{~cm}$ ) to be cleaned and thrown into ore before the next fill occur. Lately, in the Zletovo mine, the drip is obtained from the sublevel capital corridors and other mining works made for that purpose. Experience shows that getting the filling material from so-called "fillings" is not the best solution, since with their production in the hanging wall and especially in the footwall of the ore veins that are mined, there is an expansion and disruption of the stability of the excavations, that is, ore dilution (ore losses).

B) The sub-level mining excavation method, as a highly productive method in the Zletovo deposit, gives largest ore dilution during excavation. One of the reasons for this is the larger dimension of the introduced mechanization of these excavations, which inevitably results in the introduction of a larger quantity of waste material in the excavated ore. However, this unfavorable situation is further exacerbated due to disregard of the agreed planned width during the construction of the level corridors.

Organization and technical control of mining. In the company, yet is not yet taken sufficient care for the rational use of ore resources. This issue generally becomes actual only in cases when there is a problem with the input into flotation. This problem in the future will appear in an intensified form, since it will reduce the possibility of extracting extra high quality ores to cover organizational disadvantages, low productivity and so on. The entire monitoring and technical staff is not yet sufficiently stimulated for the quality of the product obtained. Practical technical control does not satisfy. First of all, this is about the layout, depth, slope and diameter of the blasting holes as well as the quality (type), and amount of the explosive. For these parameters issues, there are no technical guidelines that would be based on long-term observations for their optimum in the conditions of the Zletovo mine, because their knowledge and rational fit in practice would have a major impact on the improvement of the economic effects in the operation. Drilling and mining are the basic processes for the mining of ore veins. Money spent for them, participate with a high percentage in the cost of a ton of excavated ore and have a great impact on the level of ore dilution. An inspection and control of drilling and blasting operations should 
be performed on a constant basis and adjusted to the specific mining and geological conditions in certain parts of the deposit or ore veins.

Although there are plans for ore mining, excavation in terms of the amount of ore from individual excavations is unplanned. In this way, it is impossible to mine out ore with approximately constant content of metals in the input ore, which is unfavorably reflected on the use of metals in flotation. This comes as a result of the active mining with unequal content of useful components and therefore it is very important that the exploitation takes place according to the plan regarding the amount of ore. Although there are some recommendations regarding the quality of mining, they are not practiced in the excavation process. Miners are practically stimulated for the quantity (wagons), and not for the quality of the ore. This way of rewarding workers can often (not) intentionally encourage workers to increase ore dilution.

Here, it is important to note that from the point of view of rational use of the Zletovo mine, in the future, ore with medium content greater than the average content in the deposit should not be excavated in order to slow down trend of noticeable and permanent depletion of the deposit. During the exploitation there are large reserves in terms of obtaining ores of satisfactory quality by reducing ore dilution and possibility of selective excavation.

\section{Registration and calculation of the dilution}

When defining and calculating the ore dilution, in the Zetovo mine following types of dilution are distinguished: planned dilution, over-planned and total dilution.

Planned ore dilution, it is an imminent dilution of the ore that occurs due to the adopted minimum working width of $1.20 \mathrm{~m}$ of excavations, which represents the difference of the useful components contained in the ore veins and the content obtained by diluting this content when excavating with a minimal working width.

Planned dilution is determined even in the phase of preparatory work for exploitation, when due to the smaller thickness of the ore vein, the results are reduced to a minimum working width of $1.20 \mathrm{~m}$. This consciously includes sterile parts, which reduces the primary content of the ore vein. In the thicker $1.20 \mathrm{~m}$ veins, they are also widen up to $5-10 \mathrm{~cm}$, due to the assumption that this will occur in the process of exploitation. Even here the original results obtained are reduced to the real planned working width. The data are calculated and recorded in the book of testing as the basic document and are the basis for further upgrading. When calculating the ore reserves, the content is determined only for the planned recovery width, with pre-planned parameters. Normally, planned dilution occurs only in parts of ore veins with a thickness less than $1.20 \mathrm{~m}$. The adopted minimum width of 1.20 $\mathrm{m}$ is not based on some special tests, but more on the experience basis, although in the present conditions it should be greater in the overall dimensions of the aforementioned mechanization.

Lately, a more robust mechanization is used, in which the working width is significantly greater than the minimum working width of $1.20 \mathrm{~m}$. This is especially true in the more detailed method of exploitation, where the working width of the mechanization is used during the planning and design of the more detailed corridors, additionally enhanced for possible sub-installation. From here, the minimum width of the more detailed corridors currently in use is $1.80 \mathrm{~m}$, which significantly increases the planned ore dilution.

Over-planned ore dilution, represents the reduction of the content of the useful components in the excavated ore mass, which was due to the increased, unplanned inflow of waste parts of the surrounding rocks. In this way, great depletion of the ore is caused by an unplanned, uncontrolled and unprofessional approach in the process of exploitation.

Total ore dilution, represents the total amount of waste, which represents the difference between the thickness of the ore veins and the true width of the excavations. The total ore dilution represents mirror of the exploitation, which comprises all the objective and subjective factors. Differences highlighted through: the comparison of the thickness of the ore vein and the real width of the excavations, then between the content of the beneficial components in the ore dilution plan and the achieved dilution, the dilution calculated through the metal balance, the comparison of the surfaces, the volumes, and ultimately through direct calculations of the available ores reserves included in the exploitation indicate a high share of waste in the excavated ore, with which the original calculated amounts of the beneficial component decrease in quantity and quality .

In the Zletovo mine ore dilution is registered and calculated in two ways:

- Calculation in which the relationship between an average content of the excavated ore and the calculated average content in the ore block before the excavation is taken. This way of monitoring the ore dilution is applied to active excavations and the data for this method of calculation is taken from regular exploitation sampling.

- And through the ratio of the ore vein thickness and the planned and realized working width (through the data from the mine sampling book) using the formula: 


$$
R=\frac{d}{d_{1}} \cdot 100
$$

where: R-ore dilution (\%); d-thickness of the ore vein $(m) ; \mathrm{d}_{1}$-realized excavation width of the ore vein $(m)$.

This formula calculates the ore dilution in the excavations, but what is with the ore dilution that occurs during the excavation of the sub-level corridor. In the Zletovo mine there are no special calculations for this type of ore dilution, but World wide there are numerous examples, and largely it was confirmed that ore dilution depends of the dip angle of the ore veinn, the way it is cut with the su-level corridor, etc. (Figure 7).

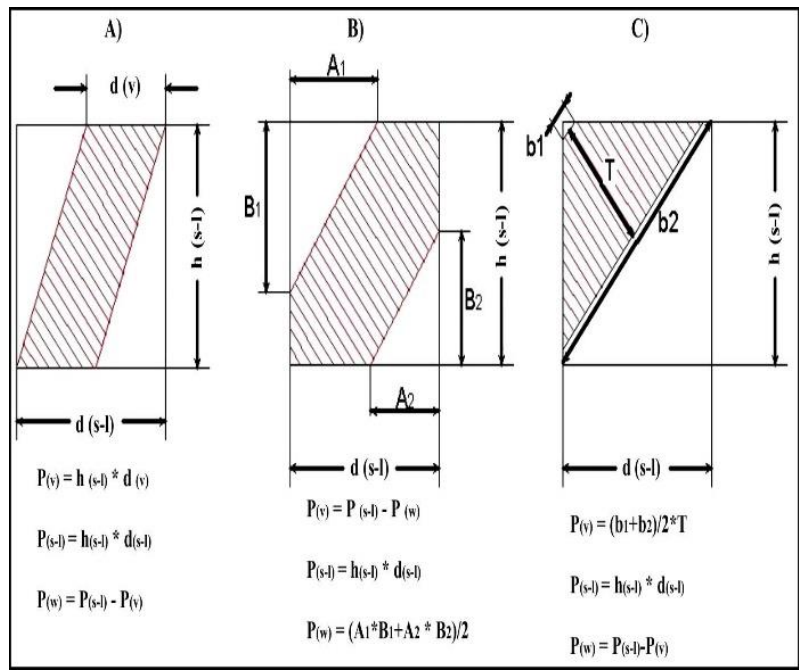

Figure 7 - Method of calculating the planned ore dilution of ore vein with a different dip angle $P(v)$ - area of ore vein $\left(\mathrm{m}^{2}\right) ; P(s-l)$ - area of sub-level corridor $\left(\mathrm{m}^{2}\right) ; P(w)$ - area of excavated waste $\left(\mathrm{m}^{2}\right) ; h(s-l)$ - height of sub-level corridor $(m) ; d(s-l)$ - depth of sub-level corridor (m); $A_{l}$ - shorter side of the triangle formed at excavated waste $(m) ; A_{2}$ - longer side of the triangle formed at excavated waste (m); $b_{1}-$ shorter side of the excavated ore vein $(m) ; b_{2}$-longer side of the excavated ore vein $(m) ; T$ - width of the ore vein $(m)$;

Planned ore dilution during making the sub-level corridor is calculated using the formula:

$$
R=\frac{P_{(w)}}{P_{(v)}} \cdot 100
$$

Based on the morphology of ore vein No.4, which is quite variable with pronounced salbands and a dip angle of 45 to $60^{\circ}$, possible cases of the cutting the ore vein with the sub-level corridor are under $B$ and $C$ from Figure 7. The case under "B" in the conditions of the Zletovo mine is the most favorable sin ce the ore vein will be fully covered and the mined ore in the excavation workings would be the easiest, so with this case we will continue with the further analysis. The case " $\mathrm{C}$ " at Figure 7, although possible, is nevertheless very unfavorable, with the ore dilution being quite high, as well as the ore losses of the mineral material. In that case, the layout of the blasting holes and the direction under which they would be drilled are very unfavorable, and the excavation of the ore would be very difficult. The first case ("A") refers to an ore vein that is much steeper than ore vein no. 4 and therefore will not be analyzed further.

When analyzing the ore dilution that occurs during making the sub-level corridor, we will analyze the cases in which the ore vein no.4, would have a different dip angle, while the thickness would be a constant at $1.47 \mathrm{~m}$ as the average thickness in the calculated ore reserves. During the analysis, the width of the sublevel corridor will be $1.57 \mathrm{~m}$, that is, the width of the ore vein no. 4 we will add $10 \mathrm{~cm}$ (left and right $5 \mathrm{~cm}$ ) as much as it will be taken to calculate the planned ore dilution, while the height will be $2.5 \mathrm{~m}$ as predicted with the more detailed digging method.

Table 1. Planned dilution in making the sub-level corridor of ore vein no. 4, considered different dip angles of ore vein.

\begin{tabular}{|l|l|l|l|l|l|l|l|l|l|l|}
\hline $\begin{array}{l}\text { Ore vein } \\
\text { dip angle }\end{array}$ & $\begin{array}{l}\mathrm{A}_{1} \\
(\mathrm{~m})\end{array}$ & $\begin{array}{l}\mathrm{A}_{2} \\
(\mathrm{~m})\end{array}$ & $\begin{array}{l}\mathrm{B}_{1} \\
(\mathrm{~m})\end{array}$ & $\begin{array}{l}\mathrm{B}_{2} \\
(\mathrm{~m})\end{array}$ & $\begin{array}{l}\mathrm{h}(\mathrm{s}-\mathrm{l}) \\
(\mathrm{m})\end{array}$ & $\begin{array}{l}\mathrm{d}(\mathrm{s}-\mathrm{l}) \\
(\mathrm{m})\end{array}$ & $\begin{array}{l}\mathrm{P}(\mathrm{v}) \\
\left(\mathrm{m}^{2}\right)\end{array}$ & $\begin{array}{l}\mathrm{P}(\mathrm{s}-1) \\
\left(\mathrm{m}^{2}\right)\end{array}$ & $\begin{array}{l}\mathrm{P}(\mathrm{w}) \\
\left(\mathrm{m}^{2}\right)\end{array}$ & $\begin{array}{l}\text { Plannned } \\
\text { ore dilut. } \\
(\%)\end{array}$ \\
\hline $\mathrm{a}=60^{\circ}$ & 0.80 & 0.52 & 1.40 & 0.99 & 2.50 & 1.57 & 3.108 & 3.925 & 0.817 & 26.3 \\
\hline $\mathrm{a}=55^{\circ}$ & 0.98 & 0.56 & 1.40 & 0.80 & 2.50 & 1.57 & 3.015 & 3.925 & 0.910 & 30.2 \\
\hline $\mathrm{a}=50^{\circ}$ & 1.25 & 0.51 & 1.49 & 0.61 & 2.50 & 1.57 & 2.838 & 3.925 & 1.087 & 38.3 \\
\hline $\mathrm{a}=45^{\circ}$ & 1.40 & 0.61 & 1.40 & 0.61 & 2.50 & 1.57 & 2.759 & 3.925 & 1.166 & 42.3 \\
\hline
\end{tabular}

Based on the calculations the following results were obtained (Table 1). Based on Table 1, it can be noted that planned ore dilution of ore vein No. 4, when making the sub-level corridor ranges from 26.3 to $42.3 \%$, it can also be noted that if the the dip angle of ore vein is steeper the ore dilution is smaller and vice versa. This analysis can be used in the preparation of monthly exploitation plans, on the basis of which it is much more realistic to predict the content of lead and zinc in the input ore in flotation, depending on which 
phase of excavation is the mine block. But the construction of the sub-level corridor represents only one stage in the subtle mining method. The excavation involves a much smaller surface area of the waste around the ore vein, which is why planned ore dilution is expected to be smaller. To make a comparison, how high would be planned ore dilution at excavation, we approached the modeling of cases in which it will be assumed that the thickness of the ore vein would be $1.47 \mathrm{~m}$, the width of excavation would be $1.57 \mathrm{~m}$, ie only $10 \mathrm{~cm}$ (left and right $5 \mathrm{~cm}$ ) from the ore vein, the height difference between the levels is $7.5 \mathrm{~m}$, only the dip angle of the ore vein would vary from 45 to $60 \mathrm{o}$, and with the excavation, the whole ore vein will be covered in height.

On the basis of these parameters, models were made (Figure 8).

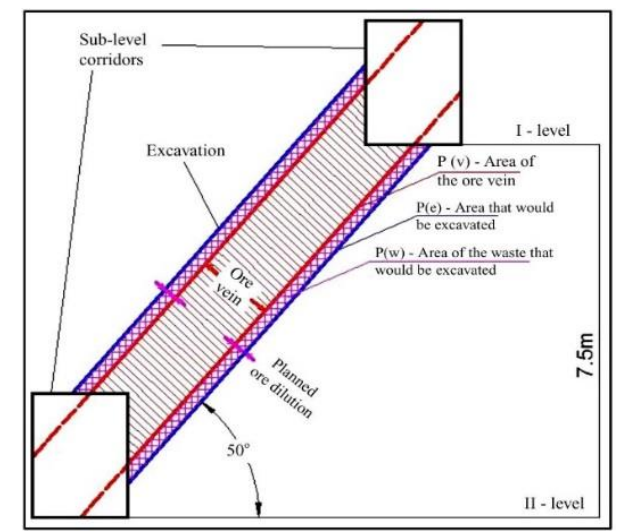

Figure 8 - Model with areas that would be mined out at ifferent dip angles of the ore vein
As can be seen the ore vein would have a different dip angle, from which the values for planned ore dilution were obtained (Table 2).

Table 2. Planned dilution during exploitation No. 4, taking into consideration the different dip angles of ore vein.

\begin{tabular}{|l|l|l|l|l|}
\hline $\begin{array}{l}\text { Ore vein } \\
\text { dip angle }\end{array}$ & $\begin{array}{l}\mathrm{P}(\mathrm{v}) \\
\left(\mathrm{m}^{2}\right)\end{array}$ & $\begin{array}{l}\mathrm{P}(\mathrm{e}) \\
\left(\mathrm{m}^{2}\right)\end{array}$ & $\begin{array}{l}\mathrm{P}(\mathrm{w}) \\
\left(\mathrm{m}^{2}\right)\end{array}$ & $\begin{array}{l}\text { Planned ore } \\
\text { dilution }(\%)\end{array}$ \\
\hline $\mathrm{a}=60^{\circ}$ & 9.65 & 10.30 & 0.65 & 6.7 \\
\hline $\mathrm{a}=55^{\circ}$ & 10.11 & 11.82 & 0.71 & 7.0 \\
\hline $\mathrm{a}=50^{\circ}$ & 11.58 & 12.44 & 0.86 & 7.4 \\
\hline $\mathrm{a}=45^{\circ}$ & 12.70 & 13.69 & 0.99 & 7.8 \\
\hline
\end{tabular}

Note: $\mathrm{P}(\mathrm{v})$-area of ore vein $\left(\mathrm{m}^{2}\right) ; \mathrm{P}(\mathrm{e})$-area of excavation $\left(\mathrm{m}^{2}\right) ; \mathrm{P}(\mathrm{w})$-an area of excavated waste $\left(\mathrm{m}^{2}\right)$

If the synthesis of the data from Table 1 and Table 2 is made, then the overall planned ore dilution of the ore vein No. 4 can be obtained, which would follow the exploitation during the making of sub-level corridor and excavation of ore itself (Table 3). Based on Table 3, it can be concluded that planned ore dilution does not increase significantly when taking into account the planned ore dilution that occurs during the construction of the sub-level corridor and the excavation.

Based on this table, the trend for increasing the planned ore dilution with decreasing of the dip angle of the ore vein is noticed, however this increase is not significant.

Table 3. Planned ore dilution of ore vein no. 4, by different dip angles of the ore vein

\begin{tabular}{|c|c|c|c|c|c|c|c|c|c|c|}
\hline \multirow{3}{*}{$\begin{array}{l}\text { Ore vein } \\
\text { dip angle }\end{array}$} & \multicolumn{3}{|c|}{$\begin{array}{l}\text { Areas that should be } \\
\text { excavated during making the } \\
\text { sub-level corridor }\end{array}$} & \multicolumn{3}{|c|}{$\begin{array}{l}\text { Areas that should be excavated } \\
\text { within the mine excavation } \\
\text { area }\end{array}$} & \multicolumn{4}{|c|}{$\begin{array}{l}\text { Plannned ore dilution at oe vein No. } 4 \\
\text { during making the sub-level } \\
\text { corridor and excavation }\end{array}$} \\
\hline & \multirow[b]{2}{*}{$\begin{array}{l}P(v) \\
m^{2}\end{array}$} & \multirow[b]{2}{*}{$\begin{array}{l}\mathrm{P}(\mathrm{s}-1) \\
\mathrm{m}^{2}\end{array}$} & \multirow[b]{2}{*}{$\begin{array}{l}\mathrm{P}(\mathrm{w}) \\
\mathrm{m}^{2}\end{array}$} & \multirow[b]{2}{*}{$\mathrm{P}(\mathrm{v}) \mathrm{m}^{2}$} & \multirow[b]{2}{*}{$\mathrm{P}(\mathrm{e}) \mathrm{m}^{2}$} & \multirow[b]{2}{*}{$\begin{array}{l}\mathrm{P}(\mathrm{w}) \\
\mathrm{m}^{2}\end{array}$} & \multicolumn{3}{|l|}{ Total } & \multirow{2}{*}{$\begin{array}{l}\text { Planned } \\
\text { ore } \\
\text { dilution } \\
(\%) \\
\end{array}$} \\
\hline & & & & & & & $\begin{array}{l}\Sigma \mathrm{P}(\mathrm{v}) \\
\mathrm{m}^{2}\end{array}$ & $\begin{array}{l}\Sigma \mathrm{P}(\mathrm{s}- \\
1+\mathrm{e}) \mathrm{m}^{2}\end{array}$ & $\begin{array}{l}\Sigma \mathrm{P}(\mathrm{w}) \\
\mathrm{m}^{2}\end{array}$ & \\
\hline$a=60^{\circ}$ & 3.11 & 3.93 & 0.82 & 9.65 & 10.30 & 0.65 & 12.76 & 14.23 & 1.47 & 11.5 \\
\hline$a=55^{\circ}$ & 3.02 & 3.93 & 0.91 & 10.11 & 10.82 & 0.71 & 13.13 & 14.75 & 1.62 & 12.3 \\
\hline$a=50^{\circ}$ & 2.84 & 3.93 & 1.09 & 11.58 & 12.44 & 0.86 & 14.42 & 16.37 & 1.95 & 13.5 \\
\hline$a=45^{\circ}$ & 2.76 & 3.93 & 1.17 & 12.70 & 13.69 & 0.99 & 15.46 & 17.62 & 2.16 & 13.9 \\
\hline
\end{tabular}

Note: $\Sigma \mathrm{P}(\mathrm{v})$-total area of ore vein $\left(\mathrm{m}^{2}\right) ; \Sigma \mathrm{P}(\mathrm{s}-\mathrm{l}+\mathrm{e})$-total area for excavation $\left(\mathrm{m}^{2}\right) ; \Sigma \mathrm{P}(\mathrm{w})$-total area of excavated waste $\left(\mathrm{m}^{2}\right)$

\section{CONCLUSION}

The ore vein No. 4 is one of the 17 ore veins in the Zletovo lead zinc mines, which have been used for the exploitation of lead-zinc ore. It has a variable dip angle of 45 to 60 and a variable thickness that is measured at $1.5 \mathrm{~m}$. The exploitation of this ore vein at higher levels above $580 \mathrm{~m}$ is made with classical excavations, in which the loss of the ore substance is $13.5 \%$ due to use of the protective pillars. In lower levels up to 450 , the exploitation is extended by more detailed methods of excavation and filling, where the dilution comes from the collapse of waste material from the sides of the hanging wall.

The planned ore dilution range from 26 to $43 \%$, while in conditions of controlled dilution with modeled parameters of vein dip angle, thickness and excavation 
method, the dilutions of individual excavations can be reduced to $10 \%$.

\section{REFERENCES}

[1] Radicević P. Ore dilution and ore loses during exploitation of ore deposits. Faculty of Mining and Geology-Belgrade, Technics 2, 135 p. [in Serbian], 1972.

[2] Efremov I. Elaborate of geological ore reserves in the Zletovo lead-zinc deposit. Lead and zinc mines Zetovo, Geological Survey-Dobrevo: Book 1, 460 p. [in Macedonian], 2002.

[3] Stankovski R, Andov R, Serafimovski Lj. Elaborate for re-categorization of geological ore reserves in the
Zletovo Pb-Zn ore deposit, situation 31.12.2012. Lead and zinc mines IMM Zletovo-Probistip, Indominerals and metals, Probistip, 103 p. [in Macedonian], 2012.

[4] Janković S, Milovanović D. Economic geology, I (Principles of economic geology). Faculty of Mining, Geology and Metalurgy-Belgrade, 249 p. [in Serbian], 1972.

[5] Bogatinovski N. Geological, morphological and economic modeling of ore vein No. 4 in the Zletovo lead and zinc mines. Master thesis, Faculty of Natural and Technical Sciences, University “Goce Delcev"-Stip, (in progress) [in Macedonian], 2017.

\section{REZIME}

\section{GUBICI I RAZBLAŽIVANJA U RUDNOJ ŽICI BR. 4 U RUDNIKU ZLETOVO, REPUBLIKA MAKEDONIJA}

Rudnici Zletovo imaju tradiciju u istraživanju i eksploataciji žičnih olovno-cinkovih ruda od skoro jednog veka. Gubici i razblaživanja oduvek su bila imperativ u proizvodnji jer se koriste tradicionalni, stari, metodi otkopavanja i niskoproduktivna mineralizacija. U uslovima otkopavanja sa klasičnim otkopima i metodom podetažnog otkopavanja sa zarušavanjem krovine, proračunati gubici rude u rudnoj žici br. 4 iznose 13.5\%, dok na nivou svih otkopa u rudnicima Zletovo razblaživanje iznosi prosečnih 10\%. Razblaživanje isto tako predstavlja važan tehnički parametar i kod njega su moguće varijante koje su proračunate. Kod analize razblaživanja koje nastaje pri izradi podetažnog hodnika sa parametrima: različiti padni ugao (45-60 ), konstantna debljina od $1.47 \mathrm{~m}$ koliko iznosi prosečna debljina rudne žice u proračunatim rudnim rezervama, širina podetažnog hodnika od $1.57 \mathrm{~m}$, ako se na širinu rudne žice br. 4 dodaju $10 \mathrm{~cm}$ (levo i desno po $5 \mathrm{~cm}$ ) koliko se i uzima pri proračunu planskog razblaživanja $i$ visina od $2.5 \mathrm{~m}$ koliko je i predviđeno metodom podetažnog otkopavanja, može se primetiti da se plansko razblaživanje pri izradi podetažnog hodnika kreće od $26.3 \%$ so $42.3 \%$. U uslovima korišćenja podetažne metode za otkopavanje izmodelirani su parametri koji omogućavaju naglašeno niža razblaživanja. Naime, debljina rudne žice bi bila $1.47 \mathrm{~m}$, širina otkopavanja $1.57 \mathrm{~m}$ ili samo $10 \mathrm{~cm}$ (levo i desno po 5 $\mathrm{cm}$ ) od rudne žice, visinska razlika izmedju etaža bi bila $7.5 \mathrm{~m}$, a jedino bi se padni ugao rudne žice menjao od 45 do $60^{\circ}$ i pri tome sa otkopom bi bila obuhvaćena cela rudna žica po visini. Na bazi ovoh parametara uradjeni su modeli u kojima bi rudna žica imala različiti padni ugao, odakle su dobijene vrednosti za plansko razblaženje od 6.7 do $7.8 \%$, a koje je naglašeno niže od prosečnih razblaživanja u rudniku Zletovo.

Ključne reči: olovno-cinkova ruda, rudnik Zletovo, rudni gubici, rudno razblaživanje, $R$. Makedonija 